\title{
Features of technological characteristics of cereal and pseudocereal flour
}

\author{
N.A. Berezina ${ }^{1, *}$, I.A. Nikitin ${ }^{2}$, E.V. Khmeleva ${ }^{1}$, N.V. Glebova ${ }^{1}$, and N.A. Makarova ${ }^{1}$ \\ ${ }^{1}$ Oryol State University named after I. S. Turgenev, 302026 Orel, Russia \\ ${ }^{2}$ Moscow State University of technologies and management named after K.G Razumovsky (The First Cossack University), 109004 \\ Moscow, Russia
}

\begin{abstract}
Carbohydrate-amylase complex of barley, rice, buckwheat and millet flours was studied. The cereal and pseudocereal flour is stated to be thermostable. Its gelatinization and liquefaction takes a long period. Addition of medium rye flour as an available and cheap source of amylolytic enzymes accelerates and increases the liquefaction of the gelatinized mass. The features of the starch component of the cereal and pseudocereal flour were found to require an increase of the pregelatinized flour preparation time. Monoand disaccharides of the pregelatinized cereal and pseudocereal flour are mainly represented by glucose. Pregelatinized cereal and pseudocereal flours (except rice flour) contain excessive amount of amino nitrogen in comparison with traditional for-bread-baking pregelatinized rye flour. Pregelatinized cereal and pseudocereal flours can be used in native or dry form. The shelf life of dry pregelatinized cereal and pseudocereal flour is 3 months.
\end{abstract}

\section{Introduction}

Cereals and pseudocereal flour is increasingly used for the production of a variety of food products [1], including bakery products [2]. However, the absence of gluten in this raw material (or its low baking value) [3], reduced amylolytic enzymes activity and starch response to their action, low water-swellability, as well as a significant number of disulfide bonds in protein substances [4] impose some restrictions on its use in baking. Studies conducted by Russian scientists have shown that, along with the above reasons, the strengthening of protein structures of baking flour when mixed with cereal and pseudocereal flour has a negative effect. At the same time, the change of the protein structures properties, and, consequently, the change of the finished product quality is manifested the stronger, the further raw protein sources are from those of typical cereals based on the morphology and biological characteristics and the longer the contact of protein substances in raw materials of different origin in the process of its joint processing is [5]. The protein structures properties of baking flour change in dough through the interaction with dissimilar protein substances of cereal and pseudocereal flour of various types. At the same time gluten becomes tougher [6] and less extensible.

The abovementioned makes it necessary to develop technological methods of cereal and pseudocereal flour use allowing neutralizing its negative impact on the finished bakery product quality.

Pregelatinized flour making was selected as the most expedient method. The technological method of making pregelatinized flour while using part of the flour required by the recipe is traditional for bread baking. While making pregelatinized flour its components change significantly: gelatinization and partial saccharification of starch, swelling and partial denaturation of protein, mono-and disaccharides, amino acids accumulation, melanoidin formation. Pregelatinized flour is a new raw product with changed physico-chemical and organoleptical properties compared to the initial raw material.

Pregelatinized flour is an obligatory component of malt rye-wheat bakery products [8].

There are various methods for making pregelatinized flour that differ in adding sequence and the ratio of raw components (flour, water, spices) [9], in heat treating methods (hot air or steam blowing, extrusion), in duration of saccharification and fermentation [10], in adding of various components that change chemical composition and properties of pregelatinized flour.

\section{Materials and methods}

The following raw materials were used: rye flour, barley flour, rice flour, buckwheat flour, millet flour, rye malt. To determine carbohydrate-amylase complex of flour, "Amylotest" apparatus was used in modes "Falling Number" and "Amylogram" in accordance with the apparatus certificate.

Pregelatinized flour was made by carefully mixing cereal and pseudocereal flour with rye malt and water having a temperature of $95-97{ }^{\circ} \mathrm{C}$, then cooling the pregelatinized flour to a temperature of $60-63{ }^{\circ} \mathrm{C}$, adding rye flour, and holding for saccharification for 100-120 minutes. Recipes of pregelatinized flour are provided in table 1.

\footnotetext{
* Corresponding author: jirdan@yandex.ru
} 
Table 1. Recipes and norms for consumption of raw materials for making pregelatinized flour.

\begin{tabular}{|c|c|c|c|c|c|c|c|c|c|}
\hline \multirow{2}{*}{$\begin{array}{c}\text { Raw Material } \\
\text { Name }\end{array}$} & \multirow{2}{*}{$\begin{array}{c}\text { Moisture, } \\
\%\end{array}$} \\
\cline { 3 - 11 } & & \multicolumn{2}{|c|}{ Raw material mass for making pregelatinized flour on 100 kg of flour and cereal and } \\
pseudocereal raw materials, kg
\end{tabular}

The glucose and maltose amount in the pregelatinized flour was estimated by special method [11]. The method is based on the sequential determination of glucose, glucose and maltose, the total amount of carbohydrates (dextrins, maltose, glucose), then the difference between the values is the amount of glucose and maltose. The sucrose amount was estimated by method based on potassium ferricyanide reduction into yellow prussiate of potash in alkaline solution with subsequent conversion to sucrose, taking into account the content of previously determined glucose and maltose. The moisture content of the pregelatinized flour was determined by drying. Acidity was determined by titration of the aqueous extract with alkali solution in the presence of an indicator, amino nitrogen was determined by formaldehyde method; the content of bisulfitebinding compounds were determined by the method based on the interaction of carbonyl compounds contained in the pregelatinized flour with sodium bisulfite [12].

\section{Results and discussion}

Carbohydrate-amylase complex is one of the main indicators of the technological properties of flour, in addition, the state of the carbohydrate-amylase complex determines the intensity of saccharification of pregelatinized flour and the content of flavorings in it.

Carbohydrate-amylase complex of barley is characterized by a high content of soluble carbohydrates $(2-3 \%)$ and starch $(75-80 \%)$, as well as by low amylolytic enzymes activity [14]. Rice contains a significant amount of starch [15], compared with other cereals and pseudocereals. Starch of barley, buckwheat, millet flour is a thermoresistant carbohydrate, which is due to the presence of amylopectin with a branched structure in its composition, the reduction of which takes more time. The composition of the carbohydrate complex of rice, barley and millet flour includes pentosans, barley flour includes $\beta$-glucans, capable of forming high-viscosity solutions and having functional properties. All these features of the carbohydrate complex of cereal and pseudocereal flour will influence on the process of pregelatinized flour making.

The index "Falling Number" is an indicator of viscosity and characterizes the liquefaction degree of the gelatinized water-flour suspension under the influence of temperature and/or enzymes included in its composition. The results of the research are shown in figure 1 .

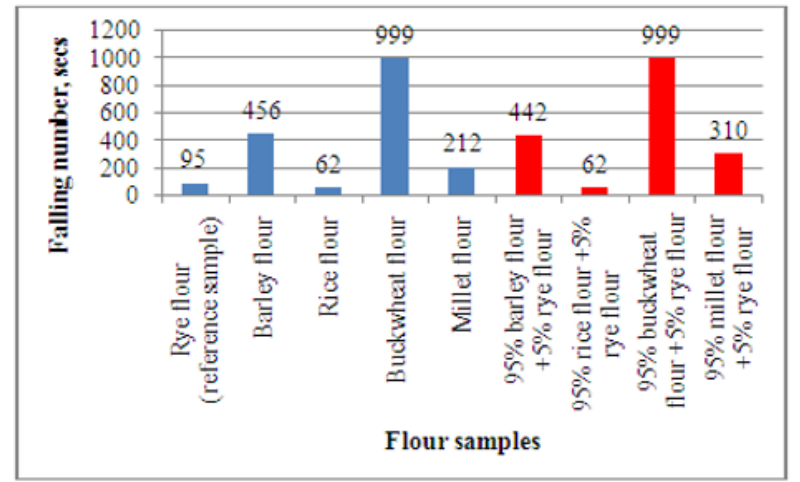

Fig. 1. The results of cereals flour falling number research

The falling number of barley, buckwheat and millet flour is determined to be 4.8, 10.5 and 2.2 times higher than that of rye flour and the falling number of rice flour is 1.5 times less as that of rye flour. This confirms the literature data on the thermal resistance of these starch types of barley, buckwheat and millet flour. When warming up in the suspension form rice flour gives liquid gelatinized mass recorded as the minimum value of the indicator "Falling Number" on the "Amylotest" apparatus.

The adding of rye flour into the cereal and pseudocereal flour suspension contributed to a decrease in the falling number of barley flour by 14 secs., the falling number of rice and buckwheat flour was not affected, and the falling number of millet flour increased by 98 secs. This shows that the amylolytic enzymes of rye flour are more complementary to the starch of barley flour, are less active compared to the enzymes of millet flour, and do not affect the starch of buckwheat and rice flour.

More in-depth study of carbohydrate-amylase complex of cereal and pseudocereal flour was carried out in the "Amylogram" mode. Amylograph curves of barley and rice flour are shown in figure 2, and those of millet and buckwheat flour are shown in figure 3 .

The initial temperature of barley and rice flour gelatinization is stated to be by 17.5 and $33.5^{\circ} \mathrm{C}$ higher, and that of buckwheat and millet flour by 6 and $17{ }^{\circ} \mathrm{C}$ higher, respectively, compared with that of the reference sample (rye flour). 


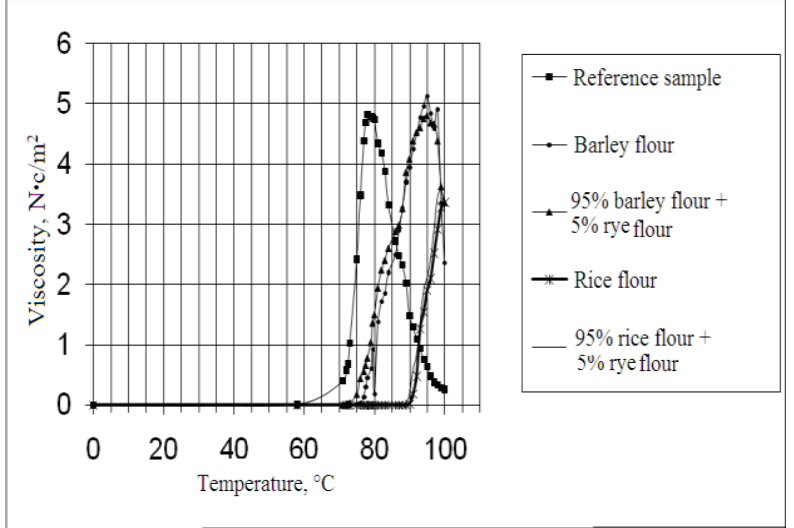

Fig. 2. Amylograph curves of barley and rice flour

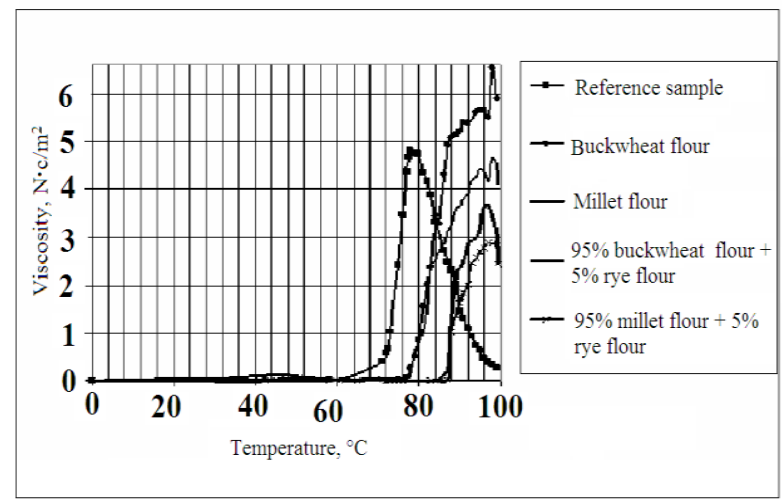

Fig. 3. Amylograph curves of buckwheat and millet flour

At the same time, the temperature of maximum viscosity of barley and buckwheat flour is by 1.1 and 1.4 times higher, and that of millet and rice flour is by 1.1 and 1.4 times lower, respectively, compared with that of the reference sample (rye flour).

The study of the results of mixing cereal and pseudocereal flour with medium rye flour as a source of enzymes showed that the initial temperature of barley, rice, millet and buckwheat flour gelatinization remains by $14.5,32,4$ and $16^{\circ} \mathrm{C}$ higher, respectively, compared with medium rye flour. However, compared with the initial values (without rye flour), the adding of rye flour helps to reduce the initial temperature of gelatinization in the studied types of cereal and pseudocereal flour by $1-3.5^{\circ} \mathrm{C}$, the temperature of maximum viscosity is 1.1-1.3 times as lower compared with that of the reference sample (rye flour).

The carbohydrate-amylase complex of cereal and pseudocereal flour is stated to be more thermostable. Gelatinization and liquefaction require a longer period of time. The adding of medium rye flour as an available and cheap source of amylolytic enzymes accelerates this process to some extent and increases the liquefaction of the gelatinized mass. Studies have shown that the features of the starch component of the cereal and pseudocereal flour require an increase of the pregelatinized flour preparation time.

Amylolytic reduction of the flour starch fraction during the pregelatinized flour making contributes to the accumulation of water-soluble sugars. The reference sample was the pregelatinized rye flour with the addition of rye malt, prepared in accordance with [8]. The duration of saccharification consisted of 120 minutes. The moisture content in the reference sample of pregelatinized flour made $75 \%$, and that in the experimental samples made $78-80 \%$. The end of the saccharification process was considered to achieve the content of reducing sugars in the experimental samples of pregelatinized flour close to that in the reference sample. The results of research are presented in table 2 .

Table 2. The influence of the pregelatinized flour saccharification duration on the accumulation of reducing sugars

\begin{tabular}{|c|c|c|c|c|c|}
\hline \multirow{2}{*}{ 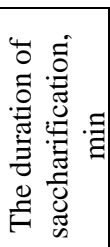 } & \multicolumn{5}{|c|}{$\begin{array}{l}\text { reducing sugars content in the } \\
\text { pregelatinized flour, } \%\end{array}$} \\
\hline & 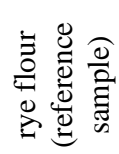 & 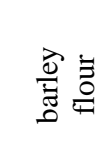 & 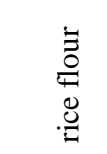 & $\begin{array}{l}\frac{\vec{d}}{\frac{C}{3}} \\
\frac{-0}{0} \\
\frac{0}{0}\end{array}$ & 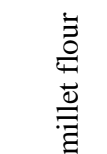 \\
\hline 30 & $6.6 \pm 0.5$ & $7.0 \pm 0.5$ & $5.4 \pm 0.5$ & $6.3 \pm 0.5$ & $7.1 \pm 0.5$ \\
\hline 60 & $7.5 \pm 0.5$ & $7.3 \pm 0.5$ & $8.2 \pm 0.5$ & $7.0 \pm 0.5$ & $8.1 \pm 0.5$ \\
\hline 90 & $8.4 \pm 0.5$ & $7.9 \pm 0.5$ & $9.3 \pm 0.5$ & $7,2 \pm 0.5$ & $8.9 \pm 0.5$ \\
\hline 120 & $8.7 \pm 0.5$ & $8.0 \pm 0.5$ & $9.7 \pm 0.5$ & $7.9 \pm 0.5$ & $8.7 \pm 0.5$ \\
\hline 150 & - & $8.2 \pm 0.5$ & - & $8.1 \pm 0.5$ & - \\
\hline 180 & - & $8.8 \pm 0.5$ & - & $8.5 \pm 0.5$ & - \\
\hline
\end{tabular}

It was found that after 30 minutes of saccharification, the lowest content of reducing sugars was observed in rice pregelatinized flour, the maximum one was in barley and millet pregelatinized flour, which is due to the high content of soluble carbohydrates in these types of flour compared with rye flour. The accumulation of reducing sugars occurred in the barley and buckwheat pregelatinized flour slowlier, which is associated with the greatest thermostability of these raw materials and their resistance to starch hydrolysis due to the presence of a larger number of branched amylopectin fractions in them. This is well illustrated by amylograph curves of these flour types that were presented earlier.

Pregelatinized flour is used in breadmaking to give a sweet taste to bakery products and to cultivate fermentation medium, that is why there is the need to determine the carbohydrate composition of the pregelatinized flour and the amount of amino nitrogen in it. The results of research are presented in figures 4 and 5 .

All types of pregelatinized flour were determined to contain mainly glucose. Millet and buckwheat pregelatinized flour show a higher content of sucrose, rice and buckwheat pregelatinized flour show a higher content of maltose.

The amount of amino nitrogen in the buckwheat, millet and barley pregelatinized flour is by $5.2-16.6 \%$ higher, and that in the rice pregelatinized flour is 2.2 times less than that in the reference sample. The low content of amino nitrogen in the rice pregelatinized flour is due to the lower amount of protein and low activity of proteolytic enzymes in it compared to other samples. The higher content of amino nitrogen in buckwheat, millet and barley pregelatinized flours is due to the high amount of protein in them compared with rye flour, and possibly due to the higher activity of proteolytic enzymes in the raw material for these types of pregelatinized flour. 


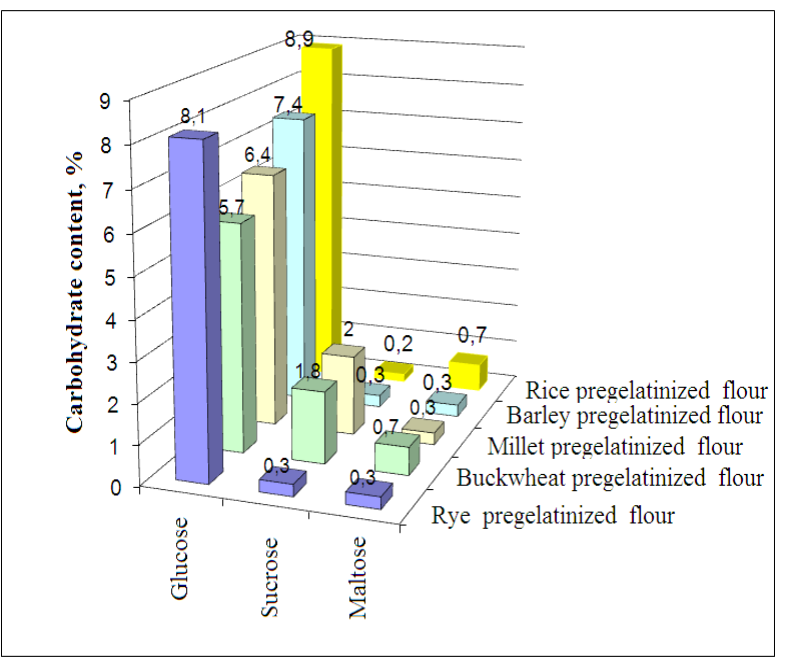

Fig. 4. The carbohydrate content of the pregelatinized cereals flour.

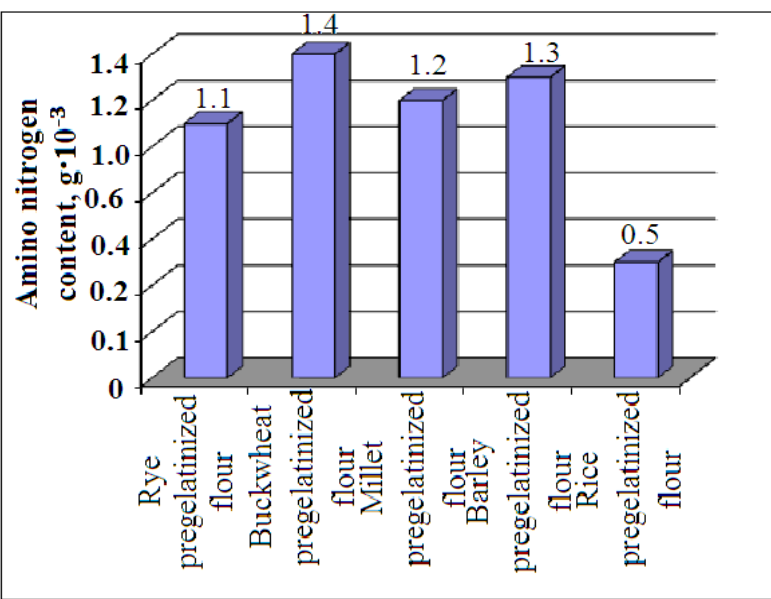

Fig. 5. The amino nitrogen content in the pregelatinized cereals flour.

Organoleptic characteristics of rice, barley, millet, buckwheat pregelatinized flour are presented in table 3 .

Rice and barley pregelatinized flours are defined to have no features of taste and flavor. Buckwheat and millet pregelatinized flours are characterized by a pleasant flavour of the flour used, which will allow to change organoleptic indicators of ready malt bakery products.

Pregelatinized cereal and pseudocereal flour can be used in the native form. Its application allows to obtain rye-wheat bakery products with physical and chemical quality indicators which are not lower than those when using pregelatinized rye flour.

To increase the shelf life of the pregelatinized flours they were dried in a convection dryer at a temperature of $80-85^{\circ} \mathrm{C}$. Pregelatinized flour was placed on the dryer trays with layer thickness of 15-20 mm. During the drying process, the changes in moisture content, titrated acidity and bisulfite-binding compounds of pregelatinized cereal and pseudocereal flour were studied. The research results are presented in table 4.

Dried pregelatinized cereal and pseudocereal flour was found to reach a moisture content of less than $15 \%$ after 12 hours of drying in a convection dryer. Titrated acidity of pregelatinized flours increases by $2-5$ degrees during drying. The content of bisulfite-binding compounds increases 1.5-2 times during 4-5 hours of drying, and then begins to decline, reaching almost the original value. The increase in the content of bisulfite-binding compounds for 4-5 hours of drying is due to the Maillard reaction between reducing sugars and amino acids of the pregelatinized flour, since there are favorable conditions for this reaction. The decrease in the content of bisulfite-binding compounds after the specified drying time is due to the volatilization of part of the carbonyl compounds as a result of temperature increase of the dried product layer.

After drying, the obtained plates were ground in an experimental mill. Sifting of crushed dry pregelatinized flours was carried out through a sieve of polyamide fabric № 27 PA-120. As a sifting result, powdered dry pregelatinized cereals flours with particle sizes corresponding to baking flour were obtained.

To determine the shelf life of dry pregelatinized cereal and pseudocereal flours, they were left for storage in closed plastic bags at a temperature of $20 \pm 2{ }^{\circ} \mathrm{C}$ and a relative humidity of $70-75 \%$. The samples of dry pregelatinized cereal and pseudocereal flours were determined to meet the requirements of Annex 1, Annex 2, p. 1.3 and 1.5 of TR CU 021/2011 "Food safety" and may have the shelf life of 3 months.

The production method of malt bakery products with pregelatinized millet flour received a patent of the Russian Federation № 2409954, the production method of malt bread with pregelatinized buckwheat flour received a patent of the Russian Federation № 2430527, the production method of bread with pregelatinized rice flour received a patent of the Russian Federation № 2429622, the mixture for pregelatinized barley flour production received a patent of the Russian Federation № 2509465.

Table 3. Organoleptic characteristics of rice, barley, millet, buckwheat pregelatinized flour.

\begin{tabular}{|c|c|c|c|c|}
\hline \multirow{2}{*}{ Indicator name } & \multicolumn{3}{|c|}{ pregelatinized flour characteristic } \\
\cline { 2 - 4 } & rice & barley & buckwheat \\
\hline Appearance & \multicolumn{3}{|c|}{ creamy consistency, free of foreign matter } \\
\hline Colour & $\begin{array}{c}\text { malty, without } \\
\text { off-odors }\end{array}$ & $\begin{array}{c}\text { malty, without off- } \\
\text { odors }\end{array}$ & $\begin{array}{c}\text { malty, with pronounced flavor } \\
\text { of buckwheat flour, without off- } \\
\text { odors }\end{array}$ & $\begin{array}{c}\text { malty, with pronounced } \\
\text { flavor of millet flour, without } \\
\text { off-odors }\end{array}$ \\
\hline Flavour & $\begin{array}{c}\text { Bread taste, } \\
\text { sweet, without } \\
\text { foreign tastes }\end{array}$ & $\begin{array}{c}\text { Bread taste, sweet, } \\
\text { without foreign } \\
\text { tastes }\end{array}$ & $\begin{array}{c}\text { Bread taste, sweet, with } \\
\text { pronounced taste of buckwheat } \\
\text { flour, without foreign tastes }\end{array}$ & $\begin{array}{c}\text { Bread taste, sweet, with } \\
\text { flour, withounced taste of millet foreign tastes }\end{array}$ \\
\hline
\end{tabular}


Table 4. The research results of changes in moisture content, titrated acidity and bisulfite-binding compounds depending on the duration of pregelatinized cereal and pseudocereal flour drying.

\begin{tabular}{|c|c|c|c|c|c|c|c|c|c|c|c|c|c|}
\hline \multirow[t]{2}{*}{ Indicator name } & \multicolumn{13}{|c|}{ Duration of pregelatinized flour drying, hour } \\
\hline & 0 & 1 & 2 & 3 & 4 & 5 & 6 & 7 & 8 & 9 & 10 & 11 & 12 \\
\hline \multirow[t]{2}{*}{ Moisture content, $\%$} & \multicolumn{13}{|c|}{ Barley } \\
\hline & $\begin{array}{l}78.0 \\
\pm 0.5\end{array}$ & $\begin{array}{l}65.3 \\
\pm 0.5\end{array}$ & $\begin{array}{l}52.0 \\
\pm 0.5\end{array}$ & $\begin{array}{l}44.1 \\
\pm 0.5\end{array}$ & $\begin{array}{l}42.1 \\
\pm 0.5\end{array}$ & $\begin{array}{l}40.2 \\
\pm 0.5\end{array}$ & $\begin{array}{l}36.7 \\
\pm 0.5\end{array}$ & $\begin{array}{l}36.0 \\
\pm 0.5\end{array}$ & $\begin{array}{l}32.0 \\
\pm 0.5\end{array}$ & $\begin{array}{l}28.4 \\
\pm 0,5\end{array}$ & $\begin{array}{l}22,1 \\
\pm 0.5\end{array}$ & $\begin{array}{l}16.3 \\
\pm 0.5\end{array}$ & $\begin{array}{l}13.5 \\
\pm 0.5\end{array}$ \\
\hline Titrated acidity, deg c & $\begin{array}{c}7.9 \pm \\
0.2\end{array}$ & $\begin{array}{c}8.2 \pm \\
0.2\end{array}$ & $\begin{array}{c}8.4 \pm \\
0.2\end{array}$ & $\begin{array}{c}8.3 \pm \\
0.2\end{array}$ & $\begin{array}{c}8.2 \pm \\
0.2\end{array}$ & $\begin{array}{c}8.5 \pm \\
0.2\end{array}$ & $\begin{array}{c}9.0 \pm \\
0.2\end{array}$ & $\begin{array}{c}9.0 \pm \\
0.2\end{array}$ & $\begin{array}{c}9.0 \pm \\
0.2\end{array}$ & $\begin{array}{c}9.1 \pm \\
0.2\end{array}$ & $\begin{array}{c}9.2 \pm \\
0.2\end{array}$ & $\begin{array}{c}9.0 \pm \\
0.2\end{array}$ & $\begin{array}{c}9.1 \pm \\
0.2\end{array}$ \\
\hline $\begin{array}{l}\text { bisulfite-binding } \\
\text { compounds content, } \\
\text { mg eq/ } 100 \mathrm{~g} \mathrm{dm}\end{array}$ & $\begin{array}{l}2.7 \pm \\
0.03\end{array}$ & $\begin{array}{l}3.2 \pm \\
0.03\end{array}$ & $\begin{array}{l}3.6 \pm \\
0.03\end{array}$ & $\begin{array}{l}3.8 \pm \\
0.03\end{array}$ & $\begin{array}{l}3.8 \pm \\
0.03\end{array}$ & $\begin{array}{l}3.9 \pm \\
0.03\end{array}$ & $\begin{array}{l}3.6 \pm \\
0.03\end{array}$ & $\begin{array}{l}3.4 \pm \\
0.03\end{array}$ & $\begin{array}{l}3.3 \pm \\
0.03\end{array}$ & $\begin{array}{l}3.0 \pm \\
0.03\end{array}$ & $\begin{array}{l}2.7 \pm \\
0.03\end{array}$ & $\begin{array}{l}2.7 \pm \\
0.03\end{array}$ & $\begin{array}{l}2.6 \pm \\
0.03\end{array}$ \\
\hline \multirow[t]{2}{*}{ Moisture content, $\%$} & \multicolumn{13}{|c|}{ Rice } \\
\hline & $\begin{array}{l}80.0 \\
\pm 0.5\end{array}$ & $\begin{array}{l}64.2 \\
\pm 0.5\end{array}$ & $\begin{array}{l}56.2 \\
\pm 0.5\end{array}$ & $\begin{array}{l}44.0 \\
\pm 0.5\end{array}$ & $\begin{array}{l}38.2 \\
\pm 0.5\end{array}$ & $\begin{array}{l}34.6 \\
\pm 0.5\end{array}$ & $\begin{array}{l}34.2 \\
\pm 0.5\end{array}$ & $\begin{array}{l}22.2 \\
\pm 0.5\end{array}$ & $\begin{array}{l}20.2 \\
\pm 0.5\end{array}$ & $\begin{array}{c}16.6 \pm \\
0.5\end{array}$ & $\begin{array}{r}14.2 \\
\pm 0.5\end{array}$ & $\begin{array}{l}13.1 \\
\pm 0.5\end{array}$ & $\begin{array}{l}12.2 \\
\pm 0.5\end{array}$ \\
\hline Titrated acidity, deg c & $\begin{array}{c}7.7 \pm \\
0.2\end{array}$ & $\begin{array}{c}8.2 \pm \\
0.2\end{array}$ & $\begin{array}{c}8.0 \pm \\
0.2\end{array}$ & $\begin{array}{c}8.2 \pm \\
0.2\end{array}$ & $\begin{array}{c}8.5 \pm \\
0.2\end{array}$ & $\begin{array}{c}8.7 \pm \\
0.2\end{array}$ & $\begin{array}{c}8.7 \pm \\
0.2\end{array}$ & $\begin{array}{c}8.5 \pm \\
0.2\end{array}$ & $\begin{array}{c}9.2 \pm \\
0.2\end{array}$ & $\begin{array}{c}9.3 \pm 0 \\
.2\end{array}$ & $\begin{array}{c}9.3 \pm \\
0.2\end{array}$ & $\begin{array}{c}9.4 \pm \\
0.2\end{array}$ & $\begin{array}{c}9.3 \pm \\
0.2\end{array}$ \\
\hline $\begin{array}{l}\text { bisulfite-binding } \\
\text { compounds content, } \\
\text { mg eq/ } 100 \mathrm{~g} \mathrm{dm}\end{array}$ & $\begin{array}{l}2.2 \pm \\
0.03\end{array}$ & $\begin{array}{l}2.7 \pm \\
0.03\end{array}$ & $\begin{array}{l}3.1 \pm \\
0.03\end{array}$ & $\begin{array}{l}3.9 \pm \\
0.03\end{array}$ & $\begin{array}{l}3.9 \pm \\
0.03\end{array}$ & $\begin{array}{l}3.8 \pm \\
0.03\end{array}$ & $\begin{array}{l}3.7 \pm \\
0.03\end{array}$ & $\begin{array}{l}3.7 \pm \\
0.03\end{array}$ & $\begin{array}{l}3.5 \pm \\
0.03\end{array}$ & $\begin{array}{c}3.3 \pm 0 \\
.03\end{array}$ & $\begin{array}{l}3.3 \pm \\
0.03\end{array}$ & $\begin{array}{l}3.2 \pm \\
0.03\end{array}$ & $\begin{array}{l}2.9 \pm \\
0.03\end{array}$ \\
\hline \multirow[t]{2}{*}{ Moisture content, $\%$} & \multicolumn{13}{|c|}{ Millet } \\
\hline & $\begin{array}{l}80.0 \\
\pm 0.5\end{array}$ & $\begin{array}{l}66.2 \\
\pm 0.5\end{array}$ & $\begin{array}{l}56.2 \\
\pm 0.5\end{array}$ & $\begin{array}{l}54.4 \\
\pm 0.5\end{array}$ & $\begin{array}{l}54.4 \\
\pm 0.5\end{array}$ & $\begin{array}{l}48.4 \\
\pm 0.5\end{array}$ & $\begin{array}{l}46.2 \\
\pm 0.5\end{array}$ & $\begin{array}{l}40.2 \\
\pm 0.5\end{array}$ & $\begin{array}{l}32.2 \\
\pm 0.5\end{array}$ & $\begin{array}{l}27.9 \\
\pm 0.5\end{array}$ & $\begin{array}{l}20.6 \\
\pm 0.5\end{array}$ & $\begin{array}{l}17.1 \\
\pm 0.5\end{array}$ & $\begin{array}{l}14.5 \\
\pm 0.5\end{array}$ \\
\hline Titrated acidity, deg c & $\begin{array}{c}8.2 \pm \\
0.2\end{array}$ & $\begin{array}{c}8.6 \pm \\
0.2\end{array}$ & $\begin{array}{c}9.6 \pm \\
0.2\end{array}$ & $\begin{array}{r}10.3 \\
\pm 0.2\end{array}$ & $\begin{array}{l}10.7 \\
\pm 0.2\end{array}$ & $\begin{array}{l}12.3 \\
\pm 0.2\end{array}$ & $\begin{array}{l}13.7 \\
\pm 0.2\end{array}$ & $\begin{array}{r}14.2 \\
\pm 0.2\end{array}$ & $\begin{array}{r}14.8 \\
\pm 0.2\end{array}$ & $\begin{array}{r}14.5 \\
\pm 0.2\end{array}$ & $\begin{array}{l}14.5 \\
\pm 0.2\end{array}$ & $\begin{array}{r}14.5 \\
\pm 0.2\end{array}$ & $\begin{array}{c}14.4 \\
\pm 0.2\end{array}$ \\
\hline $\begin{array}{l}\text { bisulfite-binding } \\
\text { compounds content, } \\
\text { mg eq/ } 100 \mathrm{~g} \mathrm{dm}\end{array}$ & $\begin{array}{l}2.1 \pm \\
0.03\end{array}$ & $\begin{array}{l}2.7 \pm \\
0.03\end{array}$ & $\begin{array}{l}3.6 \pm \\
0.03\end{array}$ & $\begin{array}{l}4.2 \pm \\
0.03\end{array}$ & $\begin{array}{l}4.8 \pm \\
0.03\end{array}$ & $\begin{array}{l}4.9 \pm \\
0.03\end{array}$ & $\begin{array}{l}5.4 \pm \\
0.03\end{array}$ & $\begin{array}{l}5.0 \pm \\
0.03\end{array}$ & $\begin{array}{l}5.0 \pm \\
0.03\end{array}$ & $\begin{array}{l}4.7 \pm \\
0.03\end{array}$ & $\begin{array}{l}3.9 \pm \\
0.03\end{array}$ & $\begin{array}{l}3.7 \pm \\
0.03\end{array}$ & $\begin{array}{l}3.7 \pm \\
0.03\end{array}$ \\
\hline & \multicolumn{13}{|c|}{ Buckwheat } \\
\hline Moisture content, $\%$ & $\begin{array}{l}78.0 \\
\pm 0.5\end{array}$ & $\begin{array}{l}65.2 \\
\pm 0.5\end{array}$ & $\begin{array}{c}60 \pm 0 \\
.5\end{array}$ & $\begin{array}{c}56 \pm 0 \\
.5\end{array}$ & $\begin{array}{c}52 \pm 0 \\
.5\end{array}$ & $\begin{array}{c}54 \pm 0 \\
.5\end{array}$ & $\begin{array}{c}48 \pm 0 \\
.5\end{array}$ & $\begin{array}{c}42 \pm 0 \\
.5\end{array}$ & $\begin{array}{c}38 \pm 0 \\
.5\end{array}$ & $\begin{array}{l}31.2 \\
\pm 0.5\end{array}$ & $\begin{array}{l}23.6 \\
\pm 0.5\end{array}$ & $\begin{array}{l}16.5 \\
\pm 0.5\end{array}$ & $\begin{array}{l}14.5 \\
\pm 0.5\end{array}$ \\
\hline Titrated acidity, deg c & $\begin{array}{c}9.4 \pm \\
0.2\end{array}$ & $\begin{array}{l}10.2 \\
\pm 0.2\end{array}$ & $\begin{array}{l}11.7 \\
\pm 0.2\end{array}$ & $\begin{array}{r}12.5 \\
\pm 0.2\end{array}$ & $\begin{array}{r}11.7 \\
\pm 0.2\end{array}$ & $\begin{array}{r}12.0 \\
\pm 0.2\end{array}$ & $\begin{array}{r}13.1 \\
\pm 0.2\end{array}$ & $\begin{array}{r}13.7 \\
\pm 0.2\end{array}$ & $\begin{array}{r}13.9 \\
\pm 0.2\end{array}$ & $\begin{array}{r}14.2 \\
\pm 0.2\end{array}$ & $\begin{array}{l}14.2 \\
\pm 0.2\end{array}$ & $\begin{array}{r}14.5 \\
\pm 0.2\end{array}$ & $\begin{array}{r}14.3 \\
\pm 0.2\end{array}$ \\
\hline $\begin{array}{l}\text { bisulfite-binding } \\
\text { compounds content, } \\
\text { mg eq/ } 100 \mathrm{~g} \mathrm{dm}\end{array}$ & $\begin{array}{l}1.8 \pm \\
0.03\end{array}$ & $\begin{array}{l}2.1 \pm \\
0.03\end{array}$ & $\begin{array}{l}2.4 \pm \\
0.03\end{array}$ & $\begin{array}{l}3.6 \pm \\
0.03\end{array}$ & $\begin{array}{l}4.6 \pm \\
0.03\end{array}$ & $\begin{array}{l}5.1 \pm \\
0.03\end{array}$ & $\begin{array}{l}4.9 \pm \\
0.03\end{array}$ & $\begin{array}{l}4.6 \pm \\
0.03\end{array}$ & $\begin{array}{l}4.7 \pm \\
0.03\end{array}$ & $\begin{array}{l}4.5 \pm \\
0.03\end{array}$ & $\begin{array}{l}4.1 \pm \\
0.03\end{array}$ & $\begin{array}{l}3.9 \pm \\
0.03\end{array}$ & $\begin{array}{l}3.7 \pm \\
0.03\end{array}$ \\
\hline
\end{tabular}

\section{Conclusion}

Theoretical and experimental justification of the cereal and pseudocereal flour use for the pregelatinized flour production for bakery products allowed to establish the following. Amylographic data confirm that the starches of this raw material are more thermostable than rye flour, their gelatinization and liquefaction requires a longer period of time.

Adding medium rye flour as an available and cheap source of amylolytic enzymes accelerates this process to some extent and increases the liquefaction of the gelatinized mass. This technological feature of cereal and pseudocereal flour requires an increase of the pregelatinized flour preparation time.

The pregelatinized cereal and pseudocereal flour contain 7.5-9.7\% of reducing sugars, have an increased titrated acidity $-9.1-14.4{ }^{\circ} \mathrm{C}$, which will have a positive influence on the fermentation medium when used in semi-finished bakery products making.

The pregelatinized cereal and pseudocereal flours meet the hygienic safety requirements for 3 months. Prospects for their use in the food production are to improve the taste and flavor, the chemical composition and functional properties of final products.

\section{Acknowledgments}

The work was carried out with the financial support of the Russian Foundation for Basic Research in the framework of grant No. 19-016-00049 "Development of a software system for automated calculation of the composition of flour mixtures of functional and dietary nutrition". 


\section{References}

1. J.L. Casper, AACC International, Inc. 14, 98 (2014)

2. B. Bigliardi, Trends in Food Sci. \& Technol. 2, 11 (2013)

3. W. Zhou, Y.H. Hui, Bakery Products Science and Technology (S.1., Wiley-Blackwell, 2014)

4. O.E. Tyurina, Development of technology for diabetic bakery products with barley flour, PhD dissertation thesis (Moscow, 2010)

5. O.V. Chugunova, N.V. Leyberova, Technol. and merchandizing of innovate. food products 4, 6 (2011)

6. L.A. Shlelenko, Development of complex improving agents for intensive technology of bakery products from wheat flour, PhD dissertation thesis (Moscow, 2001)

7. L. Ya. Auerman, Technology of bakery production (Profession, Saint-Petersburg, 2005)

8. R.D. Polandova, Collection of modern technologies of bakery products (Moscow printing house no. 2, Moscow, 2008)
9. M.Sh. Arynbayeva, L.I. Kuznetsova, O.I. Parakhina, L.V. Usova, Current trends in science and technology 1, 5 (2017)

10. L.I. Kuznetsova, N.D. Sinyavskaya, O.V. Afanasyeva, E.G. Flenova, The production of malt breads, using rye flour (Beresta, SaintPetersburg, 2003)

11. N.N. Tregubov, M.M. Tregubova, Techno-chemical control of starch-treacle production (Food industry, Moscow, 1974)

12. N.V. Labutina, S.Ya. Koryachkina, N.A. Berezina, E.V. Khmeleva, Control of raw materials, semifinished and finished bakery products (DeLi, Moscow, 2009)

13. B.S. Luh, Y.K. Liu, Rice 1, 24 (1991)

14. E.V. Niffenegger, Chemical and physical characteristics of barley flour as related to its use in baked products (Master of science in Home Economics, Montana, 1964)

15. K. Dewettinck, J. of Cereal Sci. 2, 14 (2008) 